\title{
THE ROLE OF MUSEUM'S ARCHITECTURE IN ISLAMIC COMMUNITY: MUSEUM OF ISLAMIC ART, DOHA
}

\author{
Ali A. Alraouf
}

Department Architecture and Urban Planning, College of

Engineering, Qatar University, Doha, State of Qatar

e-mail: alialraouf@yahoo.com

\begin{abstract}
As we are heading through the second decade of the $21^{\text {st }}$ century, architecture of the Islamic communities is still an unresolved dilemma. In this context, the impact of iconic buildings which claim to represent Islam or provide a contemporary approach to Islamic architecture is crucial on different levels. Therefore, a year after Museum of Islamic Art (MIA) opening in Doha, Qatar, an evaluative perspective of the institution's development story needs to be sketched. In this essay I will use MIA, Doha as a springboard for a discussion related to the museums of the $21^{\text {th }}$ century. Then, I will try to exploit the findings of this discussion in the assessment and critical review of the museum itself. The assessment will include the ability of contemporary architecture to credibly represent Islamic cultural identity. This essay will analyze how and why community participation in museums is a significant factor in bridging the gap and improving relationship between the two institutions. The social inclusion leads to trust, understanding, a sense of identity, and creating a museum that is more relevant to the community. This essay also give some suggestions on how to build bridges between museums and communities, to provide an opportunity for the people living in such communities, like Gulf ones, to find out about their own heritage and to help them realize that it is through their active participation in museum activities that heritage is kept alive. Considering Qatar's thrive into a post-oil paradigm where knowledge economy might be the generative force for development, an examination of how MIA is contributing to Qatar's new vision becomes so relevant.
\end{abstract}

Keywords: Qatar, museums, Museum of Islamic Art, knowledge-based urban development, community

\begin{abstract}
Abstrak
Di saat kita menuju dekade kedua dari abad ke-21, arsitektur dari masyarakat Islam masih merupakan sebuah dilema yang belum terselesaikan. Dalam konteks ini, dampak dari bangunan-bangunan ikonik yang mengklaim mewakili Islam atau menyediakan pendekatan kontemporer untuk arsitektur Islam sangat penting pada berbagai tingkatan. Oleh karena itu, setahun setelah pembukaan Museum of Islamic Art (MIA) di Doha, Qatar, sebuah perspektif evaluatif dari kisah pengembangan kelembagaan perlu disketsakan. Dalam esai ini, penulis menggunakan MIA, Doha sebagai batu loncatan untuk sebuah diskusi mengenai museum di abad ke-21. Kemudian, penulis juga mencoba untuk menyimpulkan hasil diskusi ini ke dalam penilaian dan review kritis terhadap museum itu sendiri. Penilaian akan mencakup kemampuan arsitektur kontemporer untuk secara kredibel dipercaya mewakili identitas budaya Islam. Tulisan ini akan menganalisis bagaimana dan mengapa partisipasi kelompok masyarakat di dalam museum menjadi faktor yang signifikan dalam menjembatani kesenjangan dan meningkatkan hubungan antara kedua lembaga. Inklusi sosial mengarahkan pada kepercayaan, pemahaman, kepekaan akan identitas, dan menciptakan sebuah museum yang lebih relevan bagi masyarakat. Esai ini juga memberikan beberapa masukan tentang bagaimana menjembatani museum dengan masyarakat, untuk memberikan kesempatan bagi masyarakat yang tinggal di dalam komunitas-komunitas tersebut, seperti masyarakat di daerah Teluk, untuk memahami kekhasan warisan mereka sendiri, serta untuk membantu mereka menyadari bahwa melalui partisipasi aktif mereka di dalam kegiatan-kegiatan museum itu, maka warisan tersebut akan tetap hidup. Mengingat perkembangan Qatar menjadi paradigma pasca-minyak dimana pengetahuan ekonomi mungkin merupakan daya generatif untuk pengembangan, penelitian tentang bagaimana MIA memberikan kontribusi untuk visi baru Qatar menjadi sangat relevan.
\end{abstract}

Kata kunci: Qatar, pengembangan kota berbasis-pengetahuan, museum, Museum of Islamic Art, masyarakat

\section{Introduction}

In recent times, extensive cultural information becomes so available through diversity of digital format. The need for the establishment of new museums is becoming an argumentative issue with virtual art museums and digital art libraries and galleries available from everyone's desktop every- where. Apparently, the governing factor is questioning the nature of the relationship between museums and communities. First, what do museums and communities have to offer each other? Second, what should be put in place to ensure that relationship between museums and communities is entertaining, healthy, and educational? Third, how 
the museum becomes an integral part of community life representing its values and identity? These are some of the fundamental questions that researchers were trying to answer as an attempt to articulate the relation between museums and communities. Most Museums in the world have been transformed and taken communities as partners in their programmes and activities ${ }^{1}$. This new approach has created a favorable working condition between museums and communities as museums are about people and created by the people themselves.

Qatar's plan for a world-class set of cultural facilities has made an impressive start with I.M. Pei's Museum of Islamic Art (MIA) in Doha. MIA opened its door to visitors in December 2008. The design of the museum went through a long path. Aka Khan Trust for Culture (AKTC) organized an international architectural competition in 1997. While getting contestants from all over the world, the jury selected eight projects for a second and final phase including signature architects like Richard Rogers, Zaha Hadid, Charles Correa and the most prominent Arab architect Rasem Badran ${ }^{2}$. The last two; Correa and Badran were selected by the jury as finalists to conduct a final rival between the two of them. A tendency towards Badran's project to be the one to build was rising especially from the client's point of view.

Without clear justification, the whole process of the competition came to a dramatic end by the client's decision to pass the project to the ChineseAmerican signature architect I.M. Pei ${ }^{3}$. The project was redesigned from scratch by this world-renowned architect, famous for designing the Louvre extension in Paris. He is also the designer of many other signature buildings around the world. In 2000, he embarked on a journey across the Muslim world in search of the spirit and essence of Islamic architecture. MIA reflects that essence as interpreted by a great contemporary architect, and provides a spectacular home for the Museum, as well as architectural landmark for Doha city.

The MIA, Doha accommodates a fascinating collection in terms of quality, historical importance and aesthetics. A range of artifacts collected from three continents (Africa-Asia, Europe) to draw a holistic portrait of Islamic art and creativity. The collection includes Qur'an early handmade pages, illustrated manuscripts, carpets, textiles, scientific apparatus, woodwork, enameled glass, and silver metalwork ${ }^{4}$. The geographical origins of the museum's collection are stretched all the way from Spain to India and Central Asia while its time frame (from the $7^{\text {th }}-19^{\text {th }}$ century) is covering up a whole millennium providing a profound insight into the cultural heritage of the Islamic world.

\section{Contemporary Muslim Community: A Defining Moment}

"Traditional Islamic civilization is marked by its emphasize upon beauty being wedded to every aspect of human life, from the chanting of the Quran to the making of pots and pans. The traditional Islamic ambience, both the plastic and the sonoral, have always been beautiful, for traditional Islam sees beauty as a complement of the Truth. $" 5$

In a world where the beauty of Islam is shadowed by fear, the art speaks to the truth of this great way of life. Contemporary Muslim communities, regionally and around the globe, are facing a defining moment. The post $9 / 11$ incident as agreed upon by different researchers established a new milestone in the contemporary history of Muslim communities $^{6}$. Crucial questions related to identity, image, misconception, and misjudgment of Islam as a religion and Muslims as part of the human community flourished in political, religious, economical, and cultural literature. Subsequently, it is becoming so clear that a comprehensive understanding about how these communities are constructing their current identity is essentially needed. Muslim communities are continually balancing the essence of their faith with the diversity of geography, politics, cultures, and economies. By focusing on constructing a reality or identity which convey the beauty of this colorful mosaic, Muslims can not only control their current reality but also help nonMuslims or rather the Western world to achieve better understanding of, and communication with Muslims individually and collectively.

While there is plenty of literature on Islamic art regarding the tools that Muslims used, the colors, and shapes, but little on what actually motivated those who designed the great Mosques in different parts of the world, who composed works of literature and works of $\mathrm{art}^{7}$. Nasr analyzed different themes of traditional art, architecture, calligraphy, poetry, prose literature, etc, as it developed in Islamic lands ${ }^{8}$. He provided a crucial explanation based on interpreting every art form as a sacred act contributing to the overall spirituality of the individual and the community. He reveals how each art form in the Islamic tradition is based upon a science of nature concerned, not with the outer appearance of things, but with their inner reality. Ranging across calligraphy, painting, architecture, literature, music, and the plastic arts, Nasr penetrates to the inner dimension of Islam and shows the role art plays in the life of individual Muslims and the community as a whole -the role of inspiring the remembrance and contemplation of God. Once Nasr establishes art as an aid and support to the spiritual life, he traces the creative act to its ultimate source: inner knowledge and barakah, or 
grace, which makes the crystallization of inner realities in form and space and time possible. Through this knowledge and grace, the author asserts, unity manifests upon the plane of multiplicity, making archetypal realities perceivable by the senses. Through this knowledge and grace, art functions as a ladder for the journey of the soul from the visible to the invisible.

Architecture and urbanism, as numerous researchers have suggested, used to be the physical representation of Muslim communities' abilities, creativity, and positive contributions in mankind development ${ }^{9}$. I would argue in this essay that better contemporary architecture and urbanism within the boundaries of Muslim communities can rejuvenate this role. MIA, Doha will be analyzed as a case study where it will be argued that it is a very profound attempt to achieve such an important goal.

\section{Architecture and Muslim Communities' Identity}

Architecture -or more broadly, the built environment- and its interface with faith has always been a most interesting point of attention. As Ozkan has argued, faiths as ways of life and social memory have had considerable influence on, among -other things- the shaping of the built environment. This relationship is seldom explored ${ }^{10}$. One of the reasons for this lack of exploration during the last hundred years is basically the spread of modernity as the most effective practical ideology. Modernity, being implicitly secular, does not encourage in our societies the exploration of the relationship of faith to other phenomena, such as buildings and architecture.

Meanwhile, it was well argued that Islamic architecture especially in traditional settlements can be a credible representation of Islamic communities' identity ${ }^{11}$. I would argue that architecture as a medium through which Islamic identity, within The Middle East, can be represented moved across three main paradigms during the last three decades. In mid of $20^{\text {th }}$ century, the waves of modernism began to reach the shore of Islamic world and affect its built environment. After the fall of modernism, post modern architects in the Middle Eastern cities resort to historical Islamic architectural styles to compose an alternative language for architecture and urbanism. This paradigm was manifested in a naive usage of historical elements usually assembled together in an artificial synthesis of forms and facades.

In the late eighties and early nineties, a considerable number of Middle Eastern cities including Gulf cities moved swiftly into a more westernized architecture to declare its thrive towards gaining international identity. Despite the accelerating pressure, a limited group of leading regional architects and planners insist on the uniqueness of their region's legacy and heritage. Affected by Frampton, critical regionalism ideas, architects like Abdel Halim Ibrahim, Rasem Badran, Riffat Jadergi, Ali Alshuaibi were capable to provide alternative architecture and urban solutions for the regional built environment of Islamic communities where Islamic architecture was not copied from historical references ${ }^{12}$. Alternatively, they perceive Islamic architecture as a source for inspiration by comprehending its concepts and governing principles. More importantly, they have initiated a creative dialogue between Islamic architecture and other schools of contemporary architecture like postmodernism, industrialism and even deconstructionism. Their attempts have resulted in number of well praised project regionally and even internationally.

The third paradigm, which is more of a concern for this essay, is where Islamic architecture was perceived as set of principles, concepts and intellectual notions. This mature and deep understanding paved the way for new architectural manifestations which are definitely inspired by Islamic architecture, yet they incorporate the rhythm and the pulse of our contemporary time. The importance of Museum of Islamic Art, Doha, as the essay would illustrate, is in its ability to be a worth analysis example of this critical paradigm in using architecture to represent Muslim communities current realities and identities.

\section{New Museums for a New Millennium}

Today, most of the museums have shifted their focus and policies in order to bridge the gap between the museums and local communities. Graham, have suggested that new demands are placed on twenty first century museum. He draws a comparison between "traditional" and "new" museum audiences stressing the challenges of avoiding social exclu$\operatorname{sion}^{13}$. By looking at the development of museum content, special groups like children, women, and families with young children can be engaged. During the past two decades, museums of all kinds have tried to become more responsive to the interests of a diverse public by shifting from the presentation of real things to the production of experiences as Hein rightly argued ${ }^{14}$. Anderson established an overall argument which reflects the unfolding thinking on what it means to be a museum in today's world. Most of the contemporary perspectives as he argues suggest the importance of the community and intensifying the role of the public ${ }^{15}$. Alexander articulated the transformations in museums definition $^{16}$. While it may appear very simple question, she asked what a museum is. She has illustrated the transformation from the historical notion of a museum is a building to protect and display valuable 
items to a museum as an educator. To relate her argument with my essay, I would highlight her perspective on art museums. Her opposition to art museum differs from science and history museums in that their collections exist to allow their viewers to experience beauty rather than to convey information is so relevant to my argument. The shift occurs with emphasize on art in everyday activities of the community, to make different social groups proud of their culture and their products. In short, define the museum as an instrument for community betterment ${ }^{17}$.

With Museums becoming more peoplecentered, idea-oriented, and contextualized, the boundaries between museums and the "real" world are becoming eroded. Setting the transition from object-centered to story-centered exhibitions in a philosophical framework, Hein contends that glorifying the museum experience at the expense of the objects deflects the Museum's educative, ethical and aesthetic roles ${ }^{18}$. But the difficult issue has always been how to effectively involve the community and maintain the relationship. In the following section, I would elaborate on MIA, Doha narrative in engaging the community. I will examine how architecture, urbanism and management of the museum are working together to achieve this goal.

\section{MIA Celebrating Islamic Culture: Critical Thoughts}

In constructing my critical thoughts and reflections for the project, I want to emphasize on three main aspects. Firstly, the museum and its role in disseminating culture, then the museum as part of Doha's new urbanism. Finally, the Museum's architecture will be analyzed to investigate its ability to act as a representation and critical interpretation of Islamic art, creativity and diversified culture. In the following sections, I would argue that the museum created a positive relation with Doha city and its community. This positive impact can be seen on different levels as follows:

\section{Museum and community involvement}

Contemporary museums started recently to adopt a new approach in considering its social responsibility. This new approach has created a favorable working condition between museums and communities as museums are about people and created by the people themselves. Most museums in the world have been transformed and considered communities as partners in their programmes and activities.

A community can be best defined as a group of people living within the same geographical area, sharing certain characteristics and common values, interests, customs, and beliefs. A museum community consists of people who visit the museum, live and work in its vicinity, are stakeholders to it, or have donated or have collections within the museum. Engagement is the level of involvement in museum activities in the areas of ideas, publicity, communications and exhibitions. MIA's management perception, of creating a bond between the Museum and the city dwellers and visitors, has emerged primarily from the notions of education and knowledge. Inviting students from schools and universities in addition to local community members to attend continuous shows, public lectures, seminars, workshops and exhibitions constructs the pillar of such a bond.

Minor yet very important information about MIA is that Qatar Museums Authority (QMA) have decided to keep the entrance to the museum to all local and expatriates from different gender and age groups totally free (Figure 1). This decision has helped in strengthening the bond between the museum and the community. Getting into the museum is achieved through two different scenarios for pedestrians. Either from the main gate located directly of the city's promenade. From the gate, visitors will ascend gradually the link leading to the main plaza and them the museum's main entrance. The other scenario for entry is via the community park adjacent to the museum which opens up towards the two sides of the museum's urban context; the city and the bay (Figure 2). The two scenarios have successfully intensified the pedestrian experience. More profoundly, they diffuse any physical or non physical boundaries between, the building, the community, and the city.

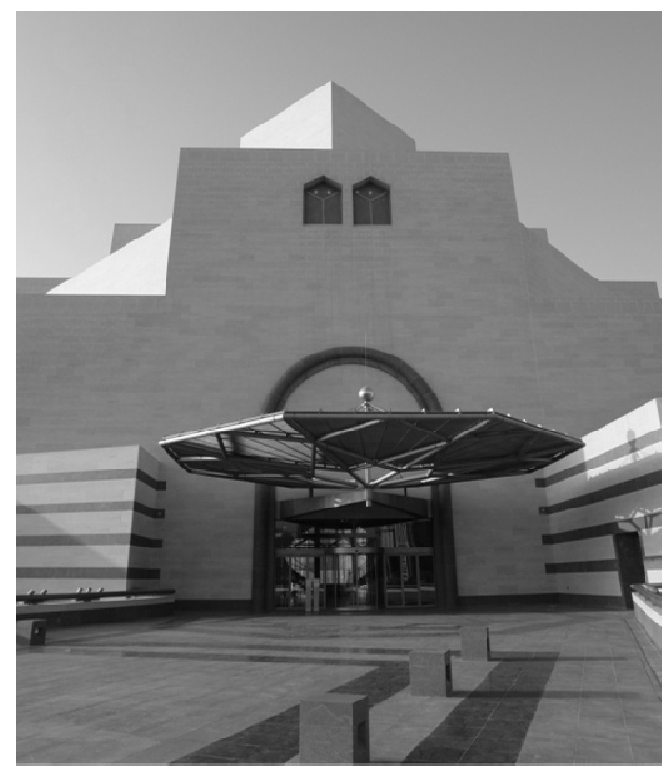

Figure 1. MIA main entrance following the palm trees passage connecting the museum with Doha city 


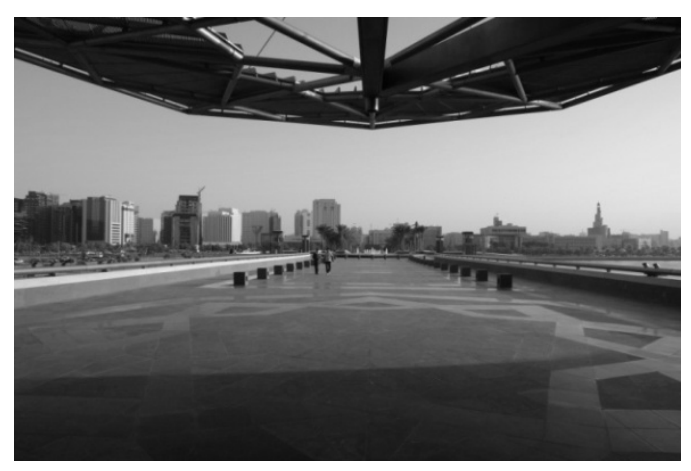

Figure 2. Looking towards the city's urbanism from the main entrance

\section{The MIA Cultural and Educational Roles}

Qatar Museums Authority (QMA) which constructs the umbrella underneath MIA and other museums ${ }^{19}$ are covered has its own cultural development strategy for Qatar. First, QMA is so interested in incorporating all museums of Qatar within the overall cultural vision of the country. Hence, constructing museums would substantiate Qatar's vision for Doha as an emerging knowledge city amid other Gulf Cities. Second, QMA is planning to have a partnership with educational institutions; locally, regionally and internationally, to enhance the cultural capabilities of children and youth. One of the main pillars of QMA vision is the creation of new learning experiences ${ }^{20}$. Museums can be directly connected to lifelong process of learning. In addition, museums can support structured or institutional education in schools by focusing on creating positive experiences for students. Hence, enjoyment and positive memories cherished should come first as Graham rightly argued ${ }^{21}$.

In the occasion of hosting Global Art Forum (GAF) at MIA premises, Abdulla Al Najjar, CEO of Qatar Museum Authority told his audience that:

"The Global Art Forum is the leading platform for cultural debate and discussion in the Middle East focusing on key issues that bring together the art scenes of this region with the rest of the world. Qatar Museums Authority has keenly hosted the Global Art Forum at the Museum of Islamic Art as it closely ties in with our vision as a vehicle for sharing culture and heritage through education and community interaction. "22

The Museum's education programs are housed in a wing to the east of the MIA main building across a fountain courtyard (Figure 3 ). The Education Wing includes the Museum library, classrooms, workshops, study spaces, and technical and storage facilities. The MIA education center opened for public in October 2009 (Figure 4). It was established as a core component of the museum since the stress on the educational role was highly emphasized from the early stages of design. The center is providing variety of activities, public lectures, interactive work- shops all of which geared towards enhancing cultural life and raising local community's awareness of art and cultural issues.

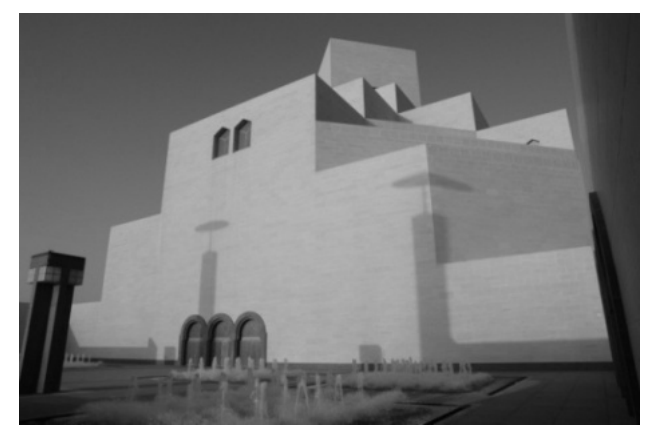

Figure 3. Western Facade creates a back ground for a city balcony characterized by dancing water fountains

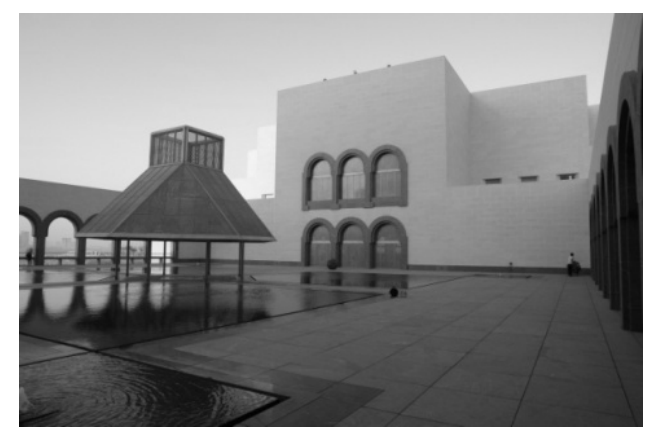

Figure 4. The education center connected to the museum via the fountain courtyard and colonnade

MIA education center managed to organize an introductory conference where the concept of education within the museum was introduced. The conference title "Partnership in Arts education: The Museum, the School and The community" is suggesting a positive understanding of the new museums role in not only enhancing cultural life but creating a strong bond between main stakeholders ${ }^{23}$. Driven by such initiative, MIA invested substantially in building bridges with community members from different age and gender and social categories. More importantly, children were seen as the main focus when it comes to issues related to raising awareness about art and culture. The typical gap between school and museum where the later was only perceived as one of the typical destinations for school trips needs to be bridged. That was precisely one of the MIA initiatives well declared intentions and goals.

\section{The Architectural and Visual Impact: MIA as an Icon}

"I believe I found what I was looking for in the Mosque of Ahmad Ibn Tulun in Cairo (876-879). The small ablutions fountain surrounded by double arcades on three sides, a slightly later addition to the architecture, is an almost Cubist expression of geometric progression from the octagon to the square 
and the square to the circle. This severe architecture comes to life in the sun, with its shadows and shades of color (Figure 5)." 24

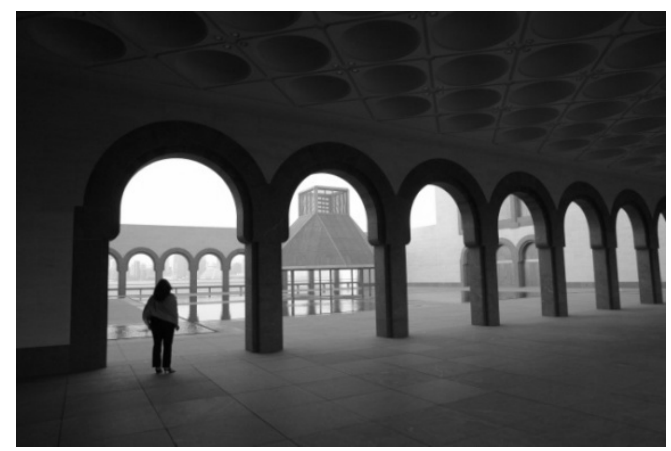

Figure 5. The Court, the Fountain and the Arcade used by Pei to articulate the connection between MIA and education center

Inspired by the magical geometry of Ahmad Ibn Tulun Mosque in the heart of Islamic Cairo (Figure 6), the museum is a contemporary representation of generative architecture produced from applying three dimensional geometrical complexities (Figure 7). The overall masses composition of the Museum is articulated of two cream-colored limestone buildings, a five-story main building, and a two-story education wing, connected across a central courtyard. Internally, the spatial composition is articulated around a main central space covered with a monumental dome and skylight. A geometric matrix transforms the dome's descent from circle to octagon, to square, and finally to four triangular flaps, which angle back at different heights to become the atrium's columns. Despite the building's size and purpose, the architecture seems positively modest. Humbleness and modesty are underlying values of Islamic architecture and urbanism.
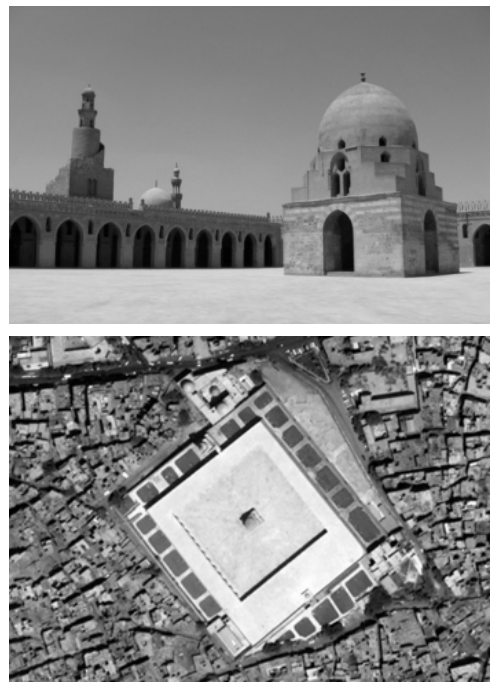

Figure 6. M. Pei was inspired by the architecture and geometrical poetics of Ibn Tulun Mosque
"I think geometry is the fundamental element of architecture, it doesn't matter is it is Islamic or Renaissance. Geometry is the framework. But if the geometry is obvious, then I've failed". ${ }^{25}$

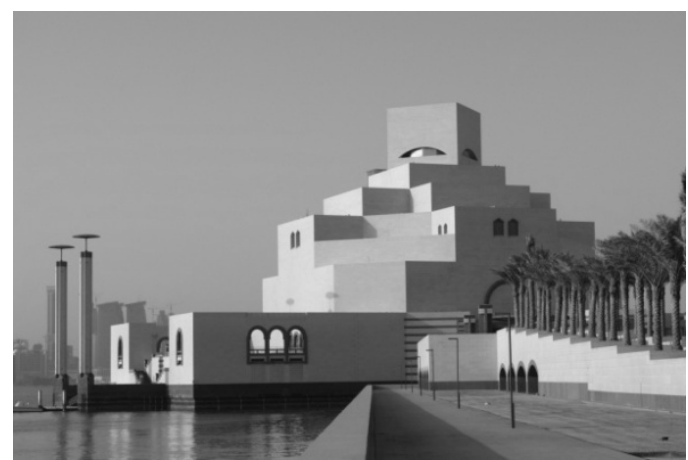

Figure 7. Geometrical composition of the MIA main mass

Visually, the museum is located on a reclaimed island right in front of the city's main promenade "Al Corniche". By being sensitive to the project context, architect I. M. Pei was able to create a landmark which is literally visible from all around Doha bay. At Pei's insistence, the museum has been built on an artificial island in Doha's broad bay, linked to the mainland by a causeway (Figure 8). He was concerned to ensure that the museum should never be overwhelmed by the skyscrapers leaping up all over Doha, which is in the process of converting itself from a Gulf version of Nice into a miniManhattan by the sea as argued.

"I didn't choose the location, I made it. I found it very tempting to do this!" ${ }^{\prime 26}$

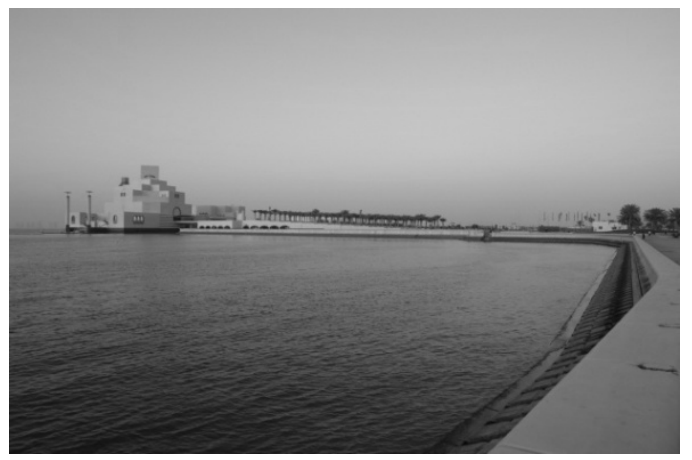

Figure 8. MIA, Doha is located on an artificial island projected from Doha's promenade to create a new visual landmark

Pei observes the unique morphology of the city waterfront and articulated the museum in a position which would engage city dwellers and visitors in an interesting visual dialogue with museum masses. More importantly, the museum architect has also created a visual link with the city from within the museum. The internal spatial composition on different levels is providing interesting glimpses towards the city's new development and vivid skyline. On the 
north side of the Museum a 45 meter tall glass curtain wall, the only major window, offers panoramic views of the Gulf and West Bay area of Doha from all five floors of the atrium. In addition, a series of outdoor spaces and terraces where introduced to play the role of city balconies for museum visitors or even for pedestrian penetrating the garden spaces and strolling around the main masses. The architecture and outdoor spaces resulted in framing a series of city views. An approach in architecture and urban design which helped Pei succesfully in stimulating visual and then intellectual dialogues between past, present and future in people's minds.

Water is one of the museum's key features. The fact that water is all around it was not enough for Pei who was well informed after his long journey learning from Islamic architecture monuments around the world that the presence of water especially inside mosques and houses is almost a scared act. Hence, Pei made the best out of it with tapestry of internal and external fountains adding positively to the sensual experience of the museum.

\section{MIA, Doha as an Identity Manifestation}

The issue of identity is of a double-faced nature when it comes to analyzing a cultural facility in an Arabic and Islamic context. First aspect is to which degree the project is in harmony with the overall identity the country is seeking for. MIA, Doha served perfectly the purpose of Doha's new identity ${ }^{27}$. Qatar did a radical transformation to go beyond the typical image of a Gulf city relaying on presumably endless assets of oil and gas. A move towards being a regional center for education, knowledge and culture is the new aspired sense of identity for Qatar. A major investment in knowledge-based urban development characterizes major projects in the country during the last five years ${ }^{28}$. All of these efforts resulted in selecting Doha as a capital for Arab culture in 2010.

The second aspect of representing the country's identity and may be the most critical one is the Arab and Muslim nature of the community. In most of the examples around Arab and Gulf cities, architecture was naively used to express artificially the Islamic identity. By focusing on reusing limited vocabulary form historical Islamic styles, architecture was not successful in this critical representation. In the case of MIA, Pei succeeds in resolving the main dilemma of Middle Eastern cities' architecture and urbanism. He created an interesting balance between Doha's contemporary aspirations without neglecting the value of its contextual heritage that the city has acquired due to belonging to Arab and Islamic world. One more virtue about Pei's approach in designing MIA, is his ability to escape from focusing on Doha's heritage since the museum was envisioned as an icon for a whole nation rather than for a city or a single country.

\section{MIA as a Branding Catalyst for Contemporary Doha}

The vision of His Highness the Emir of Qatar, Sheikh Hamad bin Khalifa Al Thani, is to mold the State of Qatar into a capital of culture. The royal family's plan is to make Doha a cultural bridge between the Middle East and the rest of the world. All this activity is testament to the fact that Qatar's enormous oil and natural gas reserves have provided it with the highest per capita income of any country in the world. It is also a mark of the cultural changes that the Amir Hamad bin Khalifa Al-Thani has brought about since he took the responsibility in 1995. Central to the Amir's vision is the recognition that, as plentiful as Qatar's natural resources may be, their value will one day be significantly diminished by the emergence of sustainable forms of energy production ${ }^{29}$. The country is therefore seeking to diversify its economy and, to that end, is investing vast sums in the development of its human capital. The creation of a world-class set of cultural facilities is a key element of this strategy, and includes the hugely ambitious plan to build 10 completely new museums.

As explained earlier, under the umbrella of Qatar Museums Authority, MIA is the leading project of His Highness's vision. As stated in the vision, The Museum of Islamic Art, Qatar, is a museum for the world. It will bring the world to Doha, but it will also connect Doha to the world. MIA is dedicated to being the foremost museum of Islamic art in the world, and as well a centre of education and information in the field of the arts of the Islamic world. Through the vision of its leadership and the dedication of its staff, the Museum of Islamic Art will manifest this commitment by establishing, preserving, and documenting a collection that reflects the vitality, the complexity, and the diversity of the arts of the Islamic world.

The well known phenomena called "Bilbao Effect" have created a new benchmark for cultural facilities' impact on cities. The Museum of art at Bilbao, Spain designed by architect Frank Gehry was envisioned by Bilbao city officials as their only salvation after years of economic crisis. An assumption which was proven to be right after the new museum helped the city to regain its vitality and became one of the top destinations for tourists visiting Spain.

Qatar vision 2030 is suggesting four pillars for a more developed and prosperous Qatar. Human and Cultural development is a core element in this vision. A reasonable justification for a tedious effort to promote Qatar and Doha as an emerging center for culture and knowledge. Cultural facilities are 
proved to be a viable tool by which cities can be marketed. It can also be seen as a catalyst for development and progress transforming cities from side to side and from rank to rank on progress scale.

Recent statistics published by Qatar museum authority have showed that MIA, Doha was visited by more than 300.000 visitors on its very first year. Speaking of people visiting cultural facilities in Gulf countries, this number is considered extraordinary. The accelerated recognition of MIA is substantiated by hosting international events throughout the first year after its inauguration. The objective of MIA hosting these cultural events is to educate the community and bridge the gap between popular and elitist culture. The first Doha Tribeca film festival (DTFF), one of the most prominent cultural events in the Middle East was among these events which have used the fascinating setting of the Museum to intensify the drama of its opening. A magnificent ceremony was held and attended by over 4000 people enjoying MIA acting as DTFF major venue.

\section{MIA Spectacle: Exhibiting vs. Freezing Culture}

The thorny issue has always been how to effectively exhibit Islamic art and heritage without establishing a negative notion regarding the lack of contemporary creative contributions from Muslim communities or artists. A common thread which I found manifested clearly in different Museums of Islamic arts including MIA, Doha is freezing a continuous cultural and transforming it into a spectacle for contemporary viewers. No one can question the contribution of Muslim artists and scientists in the development of humanity. Evidences are suggesting that their creations, inventions and intellectual thoughts have been a continuous source of inspiration and paved the way in different fields for the western civilization to be inspired with and learn from.

I would argue that art is a valuable tool in comprehending different communities cultures, it will be totally unfair to see a repeated pattern in all Islamic museums which is to focus on the value and the outcome of Islamic art from a historical perspective assuming that the present time does not exist when it comes to the contribution of Muslim artists. Most of museums of Islamic art regionally and internationally were not able to include the current paradigm as a logical continuation of Muslims contribution to art and creativity. By focusing only on historical aspects, the image of Muslims as non contributors to the current human endeavor development is highly intensified. What is the contribution of contemporary Muslim artists and how this contribution can be exhibited and in MIA is a fundamental question which I doubt, due to my critical assessment of existing Islamic museums, if there were any serious attempts to confront it.
One more concern is related to the ways by which the MIA collection is exhibited and displayed. The development of interactive displays has transformed the traditional museum world in the last decade. More importantly, Visitors are no longer satisfied by simply gazing at worthy displays in glass cases; they expect to have hands-on experience of the objects and be actively involved with the exhibits as a form of entertainment as Caulton has rightly argued ${ }^{30}$. Create and operate the effective exhibitions which achieve their educational objectives through hands-on access while encouraging a broader visitor base.

\section{Conclusion}

I shall conclude by affirming that architecture and urbanism of contemporary Muslim communities should seek to express and represent the spirit, values, creativity, underlying principles, and sacredness of Islam. Copying or reshuffling old architectural vocabularies from past eras is not only antithesis to Islamic notions of the duty of innovations and creativity but also it does contribute passively to already shattered image of Muslims across the world.

Today, Muslims not like any time before in their history, need to vigorously emphasize that their presence on earth is a sacred mission characterized by a compelling desire, faith and commitment towards enhancing mankind. Contemporary Muslims need to use art, architecture and creativity to regain their shattered image as positive members in the global development. While, due to contemporary obstacles, a tremendous effort is needed to change such an image, investing in culture and knowledge making would be of a major help.

MIA has a mission to explain Islamic art and culture to the world. In so doing, it is stating a profound example on how cultural facilities, especially in the Middle East, redraw or better remove the boundaries between people and places. The Museum is not only contributing in sustaining local and ideological identity of Qatar, but more critically it contributes positively to the country's strategic aspiration to transform Doha into a knowledge city. A quest for identity, in the contemporary moment, implies twofold pursuits. First, it would speak to the locality and relate to the community heritage and roots. The second should respect the global aspirations and each city's compelling desire to accommodate a place on the global stage and to brand itself as a global city attracting tourists, workers and global citizens.

Knowledge-based urban development should be perceived by Gulf cities as the most appropriate answer for their quest to overpass the oil economy era and moving vigorously towards post-oil one. A large part of the motivation behind the project is 
clearly the desire to establish Qatar as both a tourist destination and as an ideal place where knowledge workers might be prepared to relocate. Hence, the Museum of Islamic Art gave every indication that it was on the right track.

\section{Notes and References}

1 Jacob Nyangila. 2006. Museums and Community Involvement. Intercom Conference

2 Rasem Badran is a Jordanian architect and he is famous as believer in theory and practice in the value of Islamic heritage. He is the recipient of the prestigious award; Aka Khan Award for Islamic Architecture.

3 One of the convincing interpretations of such a decision is due to Qatar's desire to transform Doha, the capital into a global city. While Badran is with no doubt an expert in the use of Islamic architectural heritage, Pei was a more appropriate choice for globalizing Doha by putting his signature architecture in one of its prominent locations.

4 It has all been newly assembled, in large part by the Amir's cousin, Sheik Saud Al-Thani, who between 1997 and 2005 was the world's highest spending art collector. His shopping spree was eventually brought to a halt when he was placed under house arrest, accused of misappropriating funds. He was subsequently pardoned but played no part in the new museum's opening celebrations (Woodman, 2008).

5 Sayyed Hossein Nasr. 1990. Traditional Islam in the Modern World. London: Routledge. p. 20

6 Jeffrey Melnick. 2009. 9/11 Culture. New Jersey: Wiley - Blackwell

Susan Faludi. 2007. The Terror Dream: Fear and Fantasy in Post-9/11 America. New York: Metropolitan Books

Noam Chomsky \& David Barsamian. 2005. Imperial Ambition: Conversation of the Post9/11 World. New York: Metropolitan Books

7 Oleg Grabar \& Richard Ettinghausen. 1988. The Art and Architecture of Islam: 650-1250. New York: Viking Press

Barbara Brend. 1992. Islamic Art. Harvard: Harvard University Press

Robert Hillenbrand. 1998. Islamic Art and Architecture. London: Thames \& Hudson

8 Sayyed Hossein Nasr. 1987. Islamic Art and Spirituality. New York: SUNY Press

9 S. Al-Hahtlul. 1981. Tradition, Continuity, and Change in the Physical Environment: The ArabMuslim City. PhD Dissertation. MIT

Besim S. Hakim. 1988. Arabic Islamic Cities: Building and Planning Principles. 2nd Edition. London: Kegan Paul International

10 See Özkan, where he argued that in the intellectual climate of the late 1960's, modernity was challenged as an unquestionable single ideology because it failed to bring promised solutions to modern life and living. The rapid spread of the amenities and conveniences of modern life created a uniform but a less personally \& socially meaningful built environment. Süha Özkan. 1996. "Faith, Culture and Architecture". In Faith and the Built Environment: Architecture and Behavior in Islamic Cultures. Vol. 11, no 3-4, p. 181-186.

11 Ismail Serageldin. 1989. Space for Freedom. London: Butterworth Architecture

12 Kenneth Frampton. 1980. Modern Architecture: A Critical History. Oxford: OUP

13 Graham Black. 2005. The Engaging Museum: Developing Museums for Visitor Involvement. London: Routledge

14 Hilde S. Hein. 2000. The Museum in Transition: A Philosophical Perspective. Washington: Smithsonian Institution Press

15 Gail Anderson. 2004. Reinventing the Museum, Historical and Contemporary Perspectives on the Paradigm Shift. Maryland: AltaMira Press

16 Mary Alexander \& E Alexander. 2008. Museums in Motions: An Introduction to the History and Functions of Museum. 2nd edition. Maryland: AltaMira Press

17 Mary Alexander \& E Alexander. 2008. Museums in Motions: An Introduction to the History and Functions of Museum. 2nd edition. Maryland: AltaMira Press. p. 42

18 Hilde S. Hein. 2000. The Museum in Transition: A Philosophical Perspective. Washington: Smithsonian Institution Press

19 Marking the next stage of its program to develop Qatar into a hub of culture and communications for the Gulf region and the world, the Qatar Museums Authority (QMA) revealed its plans for the new National Museum of Qatar, as expressed in a striking and evocative design by Pritzker Prize-winning architect Jean Nouvel.

20 www.qma.com.qa accessed on March 14, 2010

21 Graham Black. 2005. The Engaging Museum: Developing Museums for Visitor Involvement. London: Routledge

22 www.qma.com.qa accessed on March 25, 2010

23 Museum of Islamic Art, http://www.mia.org.qa accessed March 3, 2010

24 MIA Doha by I.M. Pei, www.arcspace.com accessed on March 1, 2010

25 See Jay Merrick review in The Independent. 25 Nov. 2008

26 See Jay Merrick review in The Independent. 25 Nov. 2008

27 Qatar's vision to substantiate its position as knowledge and cultural center in the post oil paradigm was also a vehicle to create a different identity for the country's develop-ment strategy which will distinguish Qatar from other Gulf States. Building museums, universities and knowledge centers highlighted this approach. Yet, because of the strong and sometimes harsh competition between Gulf cities, Abu Dhabi challenged Qatar by the announcement of developing Sadiyyat Island as host for four mega museums designed by four of the top signature architects of our contemporary time. 
28 Ali A. Alraouf. 2008. "Emerging Middle Eastern Knowledge Cities: The Unfolding Story" in Tan Yigitcaular \& V. Koray (eds.). Knowledge Based Urban Development: Planning and Application in the Information Era. USA: IGI Global Publishing
29 Ellis Woodman. I.M. Pei's MIA opens in Doha, Review.http://www.bdonline.co.uk/story.asp? storycode $=3129204$ accessed on 28 Maret 2010

30 Caulton, Tim. 1998. Hands-on Exhibitions: Managing Interactive Museums and Science Centers. London: Routledge 